\title{
The Role of Microfinance in the Entrepreneurial Development in Pakistan
}

\author{
Hasan Raza \\ Assistant Professor, Department of Commerce \\ University of Karachi, Karachi
}

\begin{abstract}
This research was done with the prime objective to explore the role and effectiveness of microfinance in developing entrepreneurship. For economic growth and its sustainability, microfinance is deemed as one of the most necessary and operative mechanism. A sample of three hundred (350) respondents was selected based upon the basic criteria to be micro entrepreneurs using a Likert scale analysis. The facility of microfinance provision to young unemployed persons, unemployed women or poor persons has proved a tool for entrepreneurial development, reduce poverty through employment opportunity creation and a lead towards economic improvement and develop the nation. The need of entrepreneurship gets high importance on micro level due to the reason that upcoming innovations can save the resources and those resources can be utilized in more productive manner with better results.
\end{abstract}

Keywords: Microfinance, Entrepreneurship, Economic Growth, Empowerment

\section{INTRODUCTION}

Microfinance is reckoned as one of the most necessary and operative mechanism for entrepreneurial development, economic growth and its sustainability. Many researches and studies have concluded that microfinance has significantly improved living standards, empowerment and status in the society as it has increased the opportunities for selfemployment or micro entrepreneurship. During the past 10 years, microfinance programs have been introduced in many developing economies like Bangladesh, India, Nigeria, Bolivia, Kenya, Nepal, China, Indonesia, Thailand and Pakistan.

Microfinance is considered to be one of the active measures may be taken to create employment opportunities, eradicate poverty and generate economic activity, to promote entrepreneurial skills among the individuals of younger generation which will significantly facilitate economic growth, development, expansion and sustainability in Pakistan. The implication of microfinance to entrepreneurial development encouraged various developing countries to adopt it because it has become the main source of financing entrepreneurship. Nonetheless, finance is still considered as one of the major hindrances to entrepreneurial development.

In the present situation, Pakistan is facing challenges in the field of provision of employment which has increased the unemployment rate to a great extent. Although, there are various factors contributing to the high unemployment rate but comparative to all, one of the major reason in Pakistan is the low income factor. This factor has given rise to issues like, poverty, unequal allocation of income and high unemployment that Pakistan is facing now a day. According to the current scenario, 50 million people are earning US Dollar 1 per day. It has been a long time that Pakistan is going through the challenges of increasing poverty and this issue has also been noticed by United Nations as UN has already included this issue in their Millennium Development Goal. Based on their analysis, it is assessed that out of every five 
persons, one person is a victim of poverty in Pakistan. In addition, it is important to note that there is a significant gulf between the rich and the poor which has increased the income disparities. Consequently, Pakistan comes under the category of those regions where there is unequal income distribution in the world. In order to deal with this issue, social programs alone would not make much difference; therefore, for the development of a welfare state, there is a need of defensible economic growth.

The assessed market value by microfinance to be targeted in Pakistan is based on having 25 to 30 million borrowers whereas, by 2010, the set target of the government was to achieve minimum 3 million borrowers and by 2015 it was raised to 10 million(Rauf \& Mahmood, 2009).

Pakistan's Micro-finance division has developed over the previous decade and is presently serving more than 3.75 million customers through more than 50 MFPs. likewise; there have some advancement been made in the improvement of the products - enhancing past simply credit into micro-saving, micro-insurance and sanctions. These advancements are due to an immediate aftereffect of effective budgetary assurance and backing by various investors including the Government, Central Bank (SBP), Donors, PPAF, PMN, MFPs and different investors of the private subdivision. The sector has grown dramatically in the last 5 years, with total micro-credit portfolio standing at 25 billion in 2010 and around 93 billion in December 2015, and the number of active borrowers considerably increased to 3.757 million in December 2015 from 2 million in 2010 (MicroWATCH, 2015). Be that as it may, profitability and basic accomplishment markers of the division stayed powerless on the back of restricted range of operations. To add further, financial conditions including extensive inflation, power failure and common peace circumstance has hampered the reimbursement capacity of microentrepreneurs and prospective borrowers, compelling dominant part of the microfinance banks to combine their operations and concentrate on recuperations.

The major issue that micro-entrepreneur faces is shortage or non-availability of financial help to initiate or upgrade a business. This lack of finances renders efforts to solve the problem through managerial support - including enhancing entrepreneurial skills, proper selection of business and access to technology, infrastructure and markets -insufficient as both the credit facility and skill to managing business are equally vital. To tackle this problem, microfinance program groups enhancement in awareness as well as credit facilities to effectively intervene for development.

In Pakistan - a country with 192 million populations - MSMEs are limited to a few business families which operate traditional businesses in largely traditional markets (Taha, 2006).Although the MSMEs make up 85\% of the entrepreneurial sector, they contribute just a miniscule 7\% to the country's GDP(Mustafa \& Khan, 2003). This limited contribution is due to traditional operations, low entrepreneurial vision and market intelligence as well as lack of strong business models.

\section{REVIEW OF LITERATURE}

In Pakistan, the microfinance constitutes a small amount to loan that micro entrepreneurs, individuals and groups, acquire to start their businesses while personal savings are also an important part of microfinance. Microfinance intermediaries use alternative methods instead of relying on collaterals. These methods include assessment of the entrepreneur's repayment potential by using cash flow analyses, based on cash flow streams generated by activities for which loan was sought. 
In rural as well as urban areas, the primary concern of people is lack of opportunities for work as the people who have formal employment in developing countries are a minority. On the other hand, most of the people in the developing countries rely on earnings from occasional and low paid income, work on small or medium enterprises or running their own micro entrepreneurships. Micro entrepreneurships are small businesses mostly run from home and involving income making jobs like carpentry, street-trading or dairy farming etc. However, even such micro endeavors need finances which these resources less peoples gather by borrowing from friends, family members or local moneylenders. Formal bank do not provide financial services to these micro entrepreneurs as they consider such loans as insecure or not profitable while the local money lender heavily charge the people and their interest rates range from $10 \%$ to $50 \%$ a month and even more (Opportunity International, 2002) .

Saini and Bhatia (1996) also showed that there are instances when people with good entrepreneurial ability manage to boost a country's economy in spite of a scarcity of resources. They also indicated that constantly looking for resources and opportunities, these skills shape them into economic activity. The people with entrepreneurial abilities also believe that opportunities are also always there and only needed to be exploited. Hitt et al (2002) believes that a company's success is determined by capabilities more than any other resources. Jovanovic (1982) states that effective management is a factor which is more vital than capital and it can lead a company to success. They said a company's size does not matter in its success or failure. It can therefore be said that entrepreneurship is an act of changing thoughts and dreams into reality by using individual skills.

A study by Ajay and Lucky (2008) shows that the entrepreneurs with higher education and experience are more likely to be successful while Mehralizadeh and Sajady (2006) state that business success hangs on a number of the socio-economic factors including training, skills and education. David (2004) thinks that a few of the major factors that grow revenue in small business include ownership of the business, role model and high level of education.

Watjatrakul (2005) believes that both strategic and non-strategic resources are vital for the success of a firm and it is the strategic resources that enable organizations to maintain competitive advantage. The strategic resources are those resources which are imperfectly imitable, rare, non-substitutable and highly valuable. Claudia et al (2009) postulates that an entrepreneur's success is impacted by form of formal and informal support. Financial and strategic partnerships as well as industrial contacts and technology are sources of formal support while personal and community based networks form informal support (Linda et al., 2003).

Ledgerwood (1999) believes that microfinance institutions (MFIs) can provide their clients with a variety of products and services. Financial services are the most important of the services which these MFIs offer to entrepreneurs without tangible assets. These people usually belong to rural areas and are in most of the cases illiterate.

Apart from providing financial support, a need also arises to train the clients and provide them with skills required for production, business management and better access to markets so that they can make efficient use of the financial resource received. In view of this, some MFIs also give training in marketing, book-keeping and production to help develop entrepreneur's skills while some of them also offer social services -health care, education and literacy training. Both the enterprise development and social services can improve the ability of the low-income entrepreneurs to operate their businesses Legerwood (1999). 
Advocates of micro-financing claim that small loans to the micro entrepreneurs can serve as a powerful tool for reducing poverty (Khan \& Rahaman, 2007),this claim is corroborated by the UNCDF's (2009) which says that microcredit facility offered to farmers or small businesses is an effective means for enhancing economic avenues and bringing down the poor segments' vulnerabilities. It has been noted that microfinance facilitates the poor in meeting their basic needs and resultantly helps in improving their household income (Asiama \& Osei, 2007). Arguing in favor of micro-financing, Pronyk et al (2007) and some other gender activists say it is a means to empower women as it supports participation of women in economy. Boyle (2009) also states that by supporting economic participation of women, microfinance also helps in uplifting well-being of households. Littlefield (Littlefield, 2005)claims that availability of credit greatly contributes in helping the poor to not only invest in their enterprises but also give literacy to their children, bring a positive change in healthcare situation and promote wellbeing, generally. Karlan and Zinman (2006b) support this through their South African study, which shows that recipients of microcredit turned out to be better off than those who did not receive it.

Khan and Rahman (2007) suggest that people who receive microfinance facility also empower themselves and transform into extremely active participants in economy. A significant positive relationship is also observed between credit recipients and income by Priya (2006). Her finding show that program participation results in increase in income by almost $10 \%$.

Almost all studies that measure a microcredit program's performance address the effects of training programs in improving a household's ability to reap benefit of the opportunities of income generation (Otero, 1996).

However, Aguilar (2006), while studying the effect of microfinance programs on Malawi's rural farmers, reports that farmers, who borrowed from one MFI, were no better off than those who did not borrow. Augsburg (2008) also postulates that microfinance needs what is called a plus component to be successful; these plus components include training in certain areas including financial management and marketing as well as market development and managerial skills. Apparently many factors - characteristics of clients, structure of microfinance and functional arrangements - also influence the effect of microfinance, whose benefits are not always realized as they are context specific.

\section{RESEARCH OBJECTIVE}

The main objective of this study is to define and explore the effectiveness and role of microfinance in developing, nurturing and assessing the performance of micro entrepreneurship. Generally, microfinance is the only source to serve in a manner of financial sound strategy for new investors through micro and small loans that become a particular way to run small and micro businesses. In this study, microfinance is dealing with the entrepreneurs' who availed the microfinance loans and invested in entrepreneurial activity and thus and promotes entrepreneurship idea as the local player in growth engine of economy.

I. To evaluate the role of microfinance in entrepreneurial development in Pakistan

II. To measure the effectiveness of microfinance intervention in nurturing culture of micro entrepreneurship in Pakistan.

III. To identify and measure the improvement in the performance of the micro entrepreneurship if any due to participation in the micro entrepreneurship schemes

\section{DATA \& METHODOLOGY}

In this first part, the survey has been conducted which consists of a methodically designed questionnaire and based on the view to draw relevant information with ease for the 
respondents and researcher. The survey comprises of close-ended questions on likert scale of 1 - 5 ranging responses from strongly disagree to strongly agree with a provision of any additional comments from the respondents. A quantity 350 filled questionnaires were collected from respondents.

Due to the time span limitation, Cluster sampling was considered to be the best option available among different types of sampling as the microfinance institutions selected for analysis purpose have clients which are geographically dispersed and it would be quite expensive in terms of cost to reach clients especially in the case of suburb areas which were several miles away. One way to group or cluster the clients is the division of areas and selecting a cluster from each area.

\section{ANALYSIS AND DISCUSSION}

The analysis of the study is based on primary data set collected by a sample survey which is similar to or the representative of population. The analysis focuses the objective of the study and the study attempts to explain the following hypotheses.

Hypothesis 1: There is a significant positive impact of provision of microfinance facility on the Entrepreneurial development in Pakistan.

Hypothesis 2: There is a significant positive impact of provision of microfinance facility on the performance of Micro Entrepreneurship in Pakistan.

\section{Hypothesis 1: Impact of Micro Finance on Nurturing Entrepreneurship (Entrepreneurial Development)}

The section of the study discusses the impact of microfinance in extending small/ micro level entrepreneurship. The section discusses the result of respondents in which they respond to different questions. These questions are the disaggregated part of first hypothesis on "There is a significant positive impact of provision of microfinance facility on the Entrepreneurial development in Pakistan". 
Table 1 : Descriptive Statistics on MF and entrepreneurship

\begin{tabular}{|c|c|c|c|}
\hline & $\mathrm{N}$ & Mean & Std. Deviation \\
\hline $\begin{array}{l}\text { MF loans are good for nurturing } \\
\text { Entrepreneurship }\end{array}$ & 350 & 3.90 & .999 \\
\hline $\begin{array}{l}\text { Increase in income \& savings } \\
\text { encourages entrepreneurial } \\
\text { culture }\end{array}$ & 350 & 3.87 & .877 \\
\hline $\begin{array}{l}\text { Finding a best chance to secure } \\
\text { self-employment }\end{array}$ & 350 & 4.04 & .934 \\
\hline $\begin{array}{l}\text { MF opportunities help to } \\
\text { conceive and implement own } \\
\text { business idea }\end{array}$ & 350 & 4.06 & .897 \\
\hline $\begin{array}{l}\text { MF opportunities provide a } \\
\text { better support to deal with } \\
\text { business risk }\end{array}$ & 350 & 3.54 & .977 \\
\hline $\begin{array}{l}\text { MF helps to reduce the fear of } \\
\text { unemployment }\end{array}$ & 350 & 3.74 & 1.025 \\
\hline $\begin{array}{l}\text { MFI's provides operational } \\
\text { assistance and support to run } \\
\text { the business }\end{array}$ & 350 & 3.7971 & .91563 \\
\hline $\begin{array}{l}\text { Procedures of obtaining MF loan } \\
\text { is easier than conventional } \\
\text { banks }\end{array}$ & 350 & 3.51 & 1.088 \\
\hline $\begin{array}{l}\text { Provides a chance to use } \\
\text { technical, professional } \\
\text { knowledge \& skills }\end{array}$ & 350 & 3.95 & 1.013 \\
\hline Valid N (list wise) & 350 & & \\
\hline
\end{tabular}

Tables 1 shows the result of descriptive statistics on the questions asked from respondents listed in annexure. The answer is scaled between 1 to 5 values.

- Microfinance loans are good for nurturing Entrepreneurship has a mean 3.90 value of and standard deviation of 999 .

- Increase in income \& savings encourages entrepreneurial culture has a mean value of 3.87 and standard deviation of .877 .

- Finding a best chance to secure self-employment has a mean value of 4.04 and standard deviation of 934 .

- Microfinance opportunities help to conceive and implement own business idea has a mean value of 4.06 and standard deviation of 0.897 .

- Microfinance opportunities provide a better support to deal with business risk has a mean value of 3.54 and standard deviation of 0.977 .

- Microfinance helps to reduce the fear of unemployment has a mean value of 3.74 and standard deviation of 1.025 .

- Microfinance institutes provide operational assistance and support to run the business has a mean value of 3.79 and standard deviation of .915

- Procedures of obtaining microfinance loan is easier than conventional banks has a mean value of 3.51 and standard deviation of 1.088 . 
- Provides a chance to use technical, professional knowledge \& skills has a mean value of 3.95 and standard deviation of 1.013 .

The values of mean and standard deviation on the questions provides the basis to approve and accept the first hypothesis on the analysis and confirms that there is positive impact of provision of microfinance facility on the nurturing entrepreneurship (Entrepreneurial development) in Pakistan.

\section{Hypothesis 2: Impact of Micro Finance on Micro Entrepreneurship Performance}

This section discusses the impacts of microfinance on the performance on entrepreneurship performance. For the purpose of analysis nine questions were asked from different respondents on the issue if microfinance loans are supporting or having any impact on enhancing the performance of entrepreneurial ventures. Following are the descriptive results of respondents on each question.

Table 2 Descriptive Statistics on MF and Performance of Entrepreneurship

\begin{tabular}{|c|c|c|c|}
\hline & $\mathrm{N}$ & Mean & Std. Deviation \\
\hline $\begin{array}{l}\text { MF helps increase in } \\
\text { entrepreneurship profits }\end{array}$ & 350 & 3.61 & 1.034 \\
\hline $\begin{array}{l}\text { MF helps in creating } \\
\text { entrepreneurial productivity }\end{array}$ & 350 & 3.86 & .863 \\
\hline $\begin{array}{l}\text { MF creates ease in operations by } \\
\text { improving liquidity position of } \\
\text { entrepreneurship to deal with daily } \\
\text { / weekly basis payments }\end{array}$ & 350 & 3.57 & .869 \\
\hline $\begin{array}{l}\text { MF helps in enhancing use } \\
\text { technology of entrepreneurial } \\
\text { ventures }\end{array}$ & 350 & 3.57 & .984 \\
\hline $\begin{array}{l}\text { MF supports in growth in assets of } \\
\text { the entrepreneurship }\end{array}$ & 350 & 3.81 & .922 \\
\hline $\begin{array}{l}\text { MF facilitates improved access to } \\
\text { financing for expansion }\end{array}$ & 350 & 3.78 & .937 \\
\hline $\begin{array}{l}\text { MF provides easiness in the burden } \\
\text { of borrowing through convenient } \\
\text { repayment schedule }\end{array}$ & 350 & 3.55 & 1.047 \\
\hline $\begin{array}{l}\text { The product quality / production } \\
\text { facilities of the entrepreneurship } \\
\text { has improved after acquiring MF } \\
\text { loan }\end{array}$ & 350 & 3.61 & .948 \\
\hline $\begin{array}{l}\text { After obtaining MF loan, financial } \\
\text { standing of my business has } \\
\text { improved }\end{array}$ & 350 & 3.75 & .959 \\
\hline Valid N & 350 & & \\
\hline
\end{tabular}

Tables 3.10 show the result of descriptive statistics on the question asked above. The answer is scaled between 1 to 5 values. 
- Microfinance helps increase in entrepreneurship profits has a mean value of 3.61 and standard deviation is 1.034 .

- Microfinance helps in creating entrepreneurial productivity has a mean values of 3.86 and standard deviation is .863 .

- Microfinance creates ease in operations by improving liquidity position of entrepreneurship to deal with daily / weekly basis payments has a mean values of 3.57 and standard deviation is .869 .

- Microfinance helps in enhancing use technology of entrepreneurial ventures has a mean values of 3.97 and standard deviation is .984 .

- Microfinance supports in growth in assets of the entrepreneurship has a mean values of 3.81 and standard deviation is .922 .

- Microfinance facilitates improved access to financing for expansion as a mean value of 3.78 and standard deviation is 937.

- Microfinance provides easiness in the burden of borrowing through convenient repayment schedule has a mean value of 3.55 and standard deviation is 1.047

- The product quality / production facilities of the entrepreneurship has improved after acquiring MF loan has a mean values of 3.61 and standard deviation is .948

- After obtaining MF loan, financial standing of my business has improved as a mean values of 3.75 and standard deviation is .959

The values of mean and standard deviation on the questions provides the basis to approve and accept the second hypothesis on the analysis and confirms that there is a significant positive impact of provision of microfinance facility on the performance of Micro Entrepreneurship in Pakistan.

\section{CONCLUSION AND RECOMMENDATIONS}

Government has not paid the due attention to the occurrence of Entrepreneurship in its policies, which it deserves. In the parallel world economy, MSMEs are playing crucial role in its activities. As compared to other economies, in Pakistan, generally, the owners of MSMEs (especially microenterprises) run their business conventionally. They lack the interest to adapt to the changes or any innovation in the strategies or system of production which brings the problem of reduced productivity. The need of entrepreneurship gets high importance on micro level due to the reason that upcoming innovations can save the resources and those resources can be utilized in more productive manner with better results. The government and MFIs should encourage entrepreneurship and should formulate friendly policies for entrepreneurship.

Entrepreneurship has got a new face due to microfinance intervention. Better results and productivity can be achieved through implementing entrepreneurial ideas in micro-enterprises by means of microfinance. Hence, the very blend of both, that are, microfinance and entrepreneurship can be effective tool for development which can lessen the rate of poverty and can empower people swiftly. The core lower class can benefit from it and can get better income and position in the society. Microfinance can make them start their businesses and can alleviate their weaknesses. Those who cannot easily access financial institutions are the major clients of microfinance; therefore, it will also reduce poverty by producing new entrepreneurs and as a result of it generating the opportunities for employment in Pakistan.

Most of the Microfinance clients are uneducated or less educated therefore; they are unable to prepare proper records of business and to do analysis of their business. A basic training program including accounting module can be introduced to teach profit and other ratios calculation and to separate personal money from the business money and to apply different 
strategies to the business.

State Bank of Pakistan (SBP) has augmented the limit of Microfinance loan up to an amount of Rs.5,00,000, yet the amount is too little so the limit at least be extended up to 1 million. Simultaneously, it is proposed that separate departments be established to offer assistance for micro and small startups and proper guidance be given as to how microfinance loan borrowers should utilize the loan in productive manner.

The government may also allocate a dedicated fund for micro entrepreneurial development and it should be provided through the Microfinance NGOs with the provision of audit by the Government department regarding the proper utilization. The funds provided by government should be treated as interest free loans to potential and willing entrepreneur payable in installments. Besides this, the government should encourage public-private partnership wherever necessary with a range of services and more financing options.

In addition to microcredit, support services should be provided by microfinance banks. For example, training, guidance and periodic reviews of loan usage can yield positive results in employment provision and entrepreneurial development and reduction in poverty.

\section{References}

Aguilar, V. G. (2006). Is Micro Finance reaching the Poor? An Overview of Poverty argeting Methods. www.globalnet.org

Ajay, Thapa, \& Lucky, P. J. (2008). Determinants of Street Entrepreneurial Success. The Journal of Nepleese Business Studies, V (1).

Asiama, J. P., \& Osei, O. (2007). Microfinanc in Ghana: An Over View. Research Department Bank of Ghana. Economic web Institute.

Augsburg, B. (2008). Microfinance Plus - Impact of the 'plus' on customers' income in rural India. Maastricht Graduate School of Governance, University Maastricht, the Netherlands.

Boyle, G. (2009). Retrieved from www.brazencareerist.com

Claudia, C. C., G, T. L., \& Dawn, R. S. (2009). Understanding and Measuring Autonomy: An Entreneurial orientation Perspective. Entrepreneurship Theory and Practice, 33 (1), 47-69.

David, A. K. (2004). Entrepreneurship education \& incubator: pre- incubators \& sciences parks as enterprise laboratories.

Hitt, M., R, I. D., S, C. M., \& Donald, S. I. (2002). Strategic Enterpreneurship: Creating a New Mindset. Oxford. Jovanovic, B. (1982). Selection and Evolution of Industry. Econometrica, 50, 649-670.

Karlan, D., \& J Zinman. (2006b). Observing Unobserable: Indentifying Information Asymmetries with a Consumer Credit Field Experiment. Working paper.

Khan, M. A., \& Rahaman, M. A. (2007). Impact of microfinance on living standards, empowerment and poverty alleviation of poor people: a case study on micro finance in the Chittagong District of Bangladesh.

Ledgerwood, J. (1999). Microfinance Handbook: An Instituional and Financial Perspective. Washington DC: World Bank.

Littlefield, E. (2005). Microfinance - Where We Are Now and Where We Are Headed," Microfinance speech given at the International Year of Microcredit and Georgetown. Washington DC.

Mehralizadeh , Y., \& Sajady, S. (2006). A Study of Factors Related to Successful \& Failure of Entreprenuers of Small Industrial Business with Emphasis on Their Level of Education \& Training.

MicroWATCH. (2015). A Quartrly update on Microfinance Outreach in Pakistan (38).

Mustafa, I., \& Khan, F. M. (2003). Small \& Medium Enterprises in Pakistan. South Asian Journal, 4 (4).

Opportunity International. (2002). Annual Report. www.opportunity.org. 
Otero, M. (1996). Bringing Development Back into Microinance. Journal of Micro Finance, 1 (1), 8-19.

Priya , R. (2006). An Information Processing Review of the Subjective Value of Money and Prices. Journal of Business Research, 59, 10-11.

Rauf, S., \& Mahmood, T. (2009). Growth and Performance of Microfinance in Pakistan. Pakistan Economic and Social Review, 47 (1), 99-122.

Saini, J. S., \& B.S, B. (1996). Impact of Entrepreneurship Development Programmes. The Journal of Entrepreneurship, 5 (1), 65-80.

Taha, A. (2006). The Rise of the 'Gr\& Entrepreneurs' in the Czech Republic \& Their Contest for Capitalism. Czech Sociological Review.

Watjatrakul. (2005). Roadmap to Entrepreneurial: Powerful Strategies for Building a High-profit Business. AMACOM Div American Management Association ISBN 0814471900.

Yilmiz, M.H. et al (2016). Income Inequality and Its Measures: Evidence from OECD and European Countries. Journal of Poverty, Investment and Development, 20(1), 9-25.

\section{RESPONSES TABLES / DESCRIPTIVE RESULTS}

\section{Impact of Micro Finance on Nurturing Entrepreneurship (Entrepreneurial Development)}

\begin{tabular}{|ll|c|c|c|c|}
\hline \multicolumn{7}{|c|}{ MF loans are good for nurturing Entrepreneurship } \\
\hline Valid & Strongly Disagree & 10 & & & $\begin{array}{c}\text { Cumulative } \\
\text { Percent }\end{array}$ \\
& Disagree & 28 & 7.9 & 8.0 & 2.9 \\
& Neutral & 50 & 14.2 & 14.3 & 10.9 \\
& Agree & 162 & 45.9 & 46.3 & 25.1 \\
& Strongly Agree & 100 & 28.3 & 28.6 & 71.4 \\
& Total & 350 & 99.2 & 100.0 & 100.0 \\
Missing & System & 3 & .8 & & \\
Total & & 353 & 100.0 & & \\
\hline
\end{tabular}

Increase in income \& savings encourages entrepreneurial culture

\begin{tabular}{|ll|c|c|c|c|}
\hline & Frequency & Percent & $\begin{array}{c}\text { Valid } \\
\text { Percent }\end{array}$ & $\begin{array}{c}\text { Cumulative } \\
\text { Percent }\end{array}$ \\
\hline Valid & $\begin{array}{l}\text { Strongly } \\
\text { Disagree } \\
\text { Disagree }\end{array}$ & 4 & 1.1 & 1.1 & 1.1 \\
& Neutral & 20 & 5.7 & 5.7 & 6.9 \\
& Agree & 75 & 21.2 & 21.4 & 28.3 \\
& Strongly Agree & 83 & 23.5 & 23.7 & 76.3 \\
& Total & 350 & 99.2 & 100.0 & 100.0 \\
Missing & System & 3 & .8 & & \\
Total & & 353 & 100.0 & & \\
\hline
\end{tabular}


Finding a best chance to secure Self-Employment

\begin{tabular}{|ll|c|c|c|c|}
\hline & Frequency & Percent & Valid Percent & $\begin{array}{c}\text { Cumulative } \\
\text { Percent }\end{array}$ \\
\hline Valid & Strongly Disagree & 9 & 2.5 & 2.6 & 2.6 \\
& Disagree & 12 & 3.4 & 3.4 & 6.0 \\
& Neutral & 56 & 15.9 & 16.0 & 22.0 \\
& Agree & 153 & 43.3 & 43.7 & 65.7 \\
& Strongly Agree & 120 & 34.0 & 34.3 & 100.0 \\
Missing & Total & 350 & 99.2 & 100.0 & \\
Total & & 3 & .8 & & \\
\hline
\end{tabular}

MF opportunities help to conceive and implement own business idea

\begin{tabular}{|c|c|c|c|c|c|}
\hline & & Frequency & Percent & Valid Percent & $\begin{array}{c}\text { Cumulative } \\
\text { Percent }\end{array}$ \\
\hline \multirow[t]{6}{*}{ Valid } & Strongly Disagree & 6 & 1.7 & 1.7 & 1.7 \\
\hline & Disagree & 14 & 4.0 & 4.0 & 5.7 \\
\hline & Neutral & 52 & 14.7 & 14.9 & 20.6 \\
\hline & Agree & 158 & 44.8 & 45.1 & 65.7 \\
\hline & Strongly Agree & 120 & 34.0 & 34.3 & 100.0 \\
\hline & Total & 350 & 99.2 & 100.0 & \\
\hline Missing & System & 3 & .8 & & \\
\hline Total & & 353 & 100.0 & & \\
\hline
\end{tabular}

MF opportunities provide a better support to deal with business risk

\begin{tabular}{|c|c|c|c|c|c|}
\hline & & Frequency & Percent & Valid Percent & $\begin{array}{c}\text { Cumulative } \\
\text { Percent }\end{array}$ \\
\hline \multirow[t]{6}{*}{ Valid } & Strongly Disagree & 11 & 3.1 & 3.1 & 3.1 \\
\hline & Disagree & 41 & 11.6 & 11.7 & 14.9 \\
\hline & Neutral & 94 & 26.6 & 26.9 & 41.7 \\
\hline & Agree & 155 & 43.9 & 44.3 & 86.0 \\
\hline & Strongly Agree & 49 & 13.9 & 14.0 & 100.0 \\
\hline & Total & 350 & 99.2 & 100.0 & \\
\hline Missing & System & 3 & .8 & & \\
\hline Total & & 353 & 100.0 & & \\
\hline
\end{tabular}

MF helps to reduce the fear of unemployment

\begin{tabular}{|ll|c|c|c|c|}
\hline & Frequency & Percent & Valid Percent & $\begin{array}{c}\text { Cumulative } \\
\text { Percent }\end{array}$ \\
\hline Valid & Strongly Disagree & 11 & 3.1 & 3.1 & 3.1 \\
& Disagree & 28 & 7.9 & 8.0 & 11.1 \\
& Neutral & 90 & 25.5 & 25.7 & 36.9 \\
& Agree & 132 & 37.4 & 37.7 & 74.6 \\
& Strongly Agree & 89 & 25.2 & 25.4 & 100.0 \\
& Total & 350 & 99.2 & 100.0 & \\
Missing & System & 3 & .8 & & \\
Total & & 353 & 100.0 & & \\
& & & & & \\
\hline
\end{tabular}


MFI's provides operational assistance and support to run the business

\begin{tabular}{|ll|c|c|c|c|}
\hline & Frequency & Percent & Valid Percent & $\begin{array}{c}\text { Cumulative } \\
\text { Percent }\end{array}$ \\
\hline Valid & Strongly Disagree & 73 & 20.7 & 20.9 & 20.9 \\
& Disagree & 172 & 48.7 & 49.1 & 70.0 \\
& Neutral & 72 & 20.4 & 20.6 & 90.6 \\
& Agree & 27 & 7.6 & 7.7 & 98.3 \\
& Strongly Agree & 06 & 1.7 & 1.7 & 100.0 \\
Missing & Total & 350 & 99.2 & 100.0 & \\
Total & & 3 & .8 & & \\
\hline
\end{tabular}

Procedures of obtaining MF loan is easier than conventional banks

\begin{tabular}{|ll|c|c|c|c|}
\hline & Frequency & Percent & Valid Percent & $\begin{array}{c}\text { Cumulative } \\
\text { Percent }\end{array}$ \\
\hline Valid & Strongly Disagree & 15 & 4.2 & 4.3 & 4.3 \\
& Disagree & 49 & 13.9 & 14.0 & 18.3 \\
& Neutral & 98 & 27.8 & 28.0 & 46.3 \\
& Agree & 119 & 33.7 & 34.0 & 80.3 \\
& Strongly Agree & 69 & 19.5 & 19.7 & 100.0 \\
& Total & 350 & 99.2 & 100.0 & \\
Missing & System & 3 & .8 & & \\
Total & & 353 & 100.0 & & \\
\hline
\end{tabular}

Provides a chance to use technical, professional knowledge \& skills

\begin{tabular}{|ll|c|c|c|c|}
\hline & & Frequency & Percent & Valid Percent & $\begin{array}{c}\text { Cumulative } \\
\text { Percent }\end{array}$ \\
\hline Valid & Strongly Disagree & 9 & 2.5 & 2.6 & 2.6 \\
& Disagree & 25 & 7.1 & 7.1 & 9.7 \\
& Neutral & 60 & 17.0 & 17.1 & 26.9 \\
& Agree & 138 & 39.1 & 39.4 & 66.3 \\
& Strongly Agree & 118 & 33.4 & 33.7 & 100.0 \\
& Total & 350 & 99.2 & 100.0 & \\
Missing & System & 3 & .8 & & \\
Total & & 353 & 100.0 & & \\
\hline
\end{tabular}

\section{Impact of Micro Finance on Micro Entrepreneurship Performance}

MF helps increase in entrepreneurship profits

\begin{tabular}{|ll|c|c|c|c|}
\hline & Frequency & Percent & Valid Percent & $\begin{array}{c}\text { Cumulative } \\
\text { Percent }\end{array}$ \\
\hline Valid & Strongly Disagree & 14 & 4.0 & 4.0 & 4.0 \\
& Disagree & 37 & 10.5 & 10.6 & 14.6 \\
& Neutral & 87 & 24.6 & 24.9 & 39.4 \\
& Agree & 146 & 41.4 & 41.7 & 81.1 \\
& Strongly Agree & 66 & 18.7 & 18.9 & 100.0 \\
& Total & 350 & 99.2 & 100.0 & \\
Missing & System & 3 & .8 & & \\
Total & & 353 & 100.0 & & \\
\hline
\end{tabular}


MF helps in creating entrepreneurial productivity

\begin{tabular}{|ll|c|c|c|c|}
\hline & Frequency & Percent & Valid Percent & $\begin{array}{c}\text { Cumulative } \\
\text { Percent }\end{array}$ \\
\hline Valid & Strongly Disagree & 3 & .8 & .9 & .9 \\
& Disagree & 26 & 7.4 & 7.4 & 8.3 \\
& Neutral & 62 & 17.6 & 17.7 & 26.0 \\
& Agree & 185 & 52.4 & 52.9 & 78.9 \\
& Strongly Agree & 74 & 21.0 & 21.1 & 100.0 \\
& Total & 350 & 99.2 & 100.0 & \\
Missing & System & 3 & .8 & & \\
\cline { 3 - 5 } & & 353 & 100.0 & & \\
\hline
\end{tabular}

MF creates ease in operations by improving liquidity position of entrepreneurship to deal with daily / weekly basis payments

\begin{tabular}{|ll|c|c|c|c|}
\hline & Frequency & Percent & Valid Percent & $\begin{array}{c}\text { Cumulative } \\
\text { Percent }\end{array}$ \\
\hline Valid & Strongly Disagree & 5 & 1.4 & 1.4 & 1.4 \\
& Disagree & 35 & 9.9 & 10.0 & 11.4 \\
& Neutral & 105 & 29.7 & 30.0 & 41.4 \\
& Agree & 166 & 47.0 & 47.4 & 88.9 \\
& Strongly Agree & 39 & 11.0 & 11.1 & 100.0 \\
Missing & Total & 350 & 99.2 & 100.0 & \\
Total & & 3 & .8 & & \\
\hline
\end{tabular}

MF helps in enhancing use technology of entrepreneurial ventures

\begin{tabular}{|c|c|c|c|c|c|}
\hline & & Frequency & Percent & Valid Percent & $\begin{array}{c}\text { Cumulative } \\
\text { Percent }\end{array}$ \\
\hline \multirow[t]{6}{*}{$\overline{\text { Valid }}$} & Strongly Disagree & 7 & 2.0 & 2.0 & 2.0 \\
\hline & Disagree & 45 & 12.7 & 12.9 & 14.9 \\
\hline & Neutral & 99 & 28.0 & 28.3 & 43.1 \\
\hline & Agree & 139 & 39.4 & 39.7 & 82.9 \\
\hline & Strongly Agree & 60 & 17.0 & 17.1 & 100.0 \\
\hline & Total & 350 & 99.2 & 100.0 & \\
\hline Missing & System & 3 & .8 & & \\
\hline Total & & 353 & 100.0 & & \\
\hline
\end{tabular}

MF supports in growth in assets of the entrepreneurship

\begin{tabular}{|ll|c|c|c|c|}
\hline & Frequency & Percent & Valid Percent & $\begin{array}{c}\text { Cumulative } \\
\text { Percent }\end{array}$ \\
\hline Valid & Strongly Disagree & 5 & 1.4 & 1.4 & 1.4 \\
& Disagree & 26 & 7.4 & 7.4 & 8.9 \\
& Neutral & 79 & 22.4 & 22.6 & 31.4 \\
& Agree & 159 & 45.0 & 45.4 & 76.9 \\
& Strongly Agree & 81 & 22.9 & 23.1 & 100.0 \\
& Total & 350 & 99.2 & 100.0 & \\
Missing & System & 3 & .8 & & \\
Total & & 353 & 100.0 & & \\
\hline
\end{tabular}


MF facilitates improved access to financing for expansion

\begin{tabular}{|ll|c|c|c|c|}
\hline & Frequency & Percent & Valid Percent & $\begin{array}{c}\text { Cumulative } \\
\text { Percent }\end{array}$ \\
\hline Valid & Strongly Disagree & 7 & 2.0 & 2.0 & 2.0 \\
& Disagree & 27 & 7.6 & 7.7 & 9.7 \\
& Neutral & 78 & 22.1 & 22.3 & 32.0 \\
& Agree & 163 & 46.2 & 46.6 & 78.6 \\
& Strongly Agree & 75 & 21.2 & 21.4 & 100.0 \\
& Total & 350 & 99.2 & 100.0 & \\
Missing & System & 3 & .8 & & \\
\hline
\end{tabular}

MF provides easiness in the burden of borrowing through convenient repayment schedule

\begin{tabular}{|ll|c|c|c|c|}
\hline & Frequency & Percent & Valid Percent & $\begin{array}{c}\text { Cumulative } \\
\text { Percent }\end{array}$ \\
\hline Valid & Strongly Disagree & 13 & 3.7 & 3.7 & 3.7 \\
& Disagree & 44 & 12.5 & 12.6 & 16.3 \\
& Neutral & 94 & 26.6 & 26.9 & 43.1 \\
& Agree & 134 & 38.0 & 38.3 & 81.4 \\
& Strongly Agree & 65 & 18.4 & 18.6 & 100.0 \\
Missing & Total & 350 & 99.2 & 100.0 & \\
Total & & 3 & .8 & & \\
\hline
\end{tabular}

The product quality / production facilities of the entrepreneurship has improved

\begin{tabular}{|c|c|c|c|c|c|}
\hline & & Frequency & Percent & Valid Percent & $\begin{array}{c}\text { Cumulative } \\
\text { Percent }\end{array}$ \\
\hline \multirow[t]{6}{*}{ Valid } & Strongly Disagree & 9 & 2.5 & 2.6 & 2.6 \\
\hline & Disagree & 35 & 9.9 & 10.0 & 12.6 \\
\hline & Neutral & 93 & 26.3 & 26.6 & 39.1 \\
\hline & Agree & 160 & 45.3 & 45.7 & 84.9 \\
\hline & Strongly Agree & 53 & 15.0 & 15.1 & 100.0 \\
\hline & Total & 350 & 99.2 & 100.0 & \\
\hline Missing & System & 3 & .8 & & \\
\hline Total & & 353 & 100.0 & & \\
\hline
\end{tabular}

After obtaining MF loan, financial standing of my business has improved

\begin{tabular}{|ll|c|c|c|c|}
\hline & Frequency & Percent & Valid Percent & $\begin{array}{c}\text { Cumulative } \\
\text { Percent }\end{array}$ \\
\hline Valid & Strongly Disagree & 11 & 3.1 & 3.1 & 3.1 \\
& Disagree & 26 & 7.4 & 7.4 & 10.6 \\
& Neutral & 70 & 19.8 & 20.0 & 30.6 \\
& Agree & 174 & 49.3 & 49.7 & 80.3 \\
& Strongly Agree & 69 & 19.5 & 19.7 & 100.0 \\
& Total & 350 & 99.2 & 100.0 & \\
Missing & System & 3 & .8 & & \\
Total & & 353 & 100.0 & & \\
\hline
\end{tabular}

